\title{
Evolutionary entrepreneurial ecosystems: a research pathway
}

\author{
Daniel Sunghwan Cho $\mathbb{D}$ - Paul Ryan $(\mathbb{D})$ \\ Giulio Buciuni (D)
}

Accepted: 21 March 2021 / Published online: 14 May 2021

(C) The Author(s) 2021

\begin{abstract}
The recent widespread interest of policy in entrepreneurial ecosystems has been complemented by a burgeoning academic research output. This research to date may be broadly categorized as focusing on place, actors, governance, and evolution. Of these groupings, evolutionary processes have been paid least attention despite their centrality to a dynamic ecosystem phenomenon that evolves from an origin through processes of growth, adaptation, and resilience. To redress this imbalance, we frame a future research agenda on evolutionary processes of entrepreneurial ecosystems. Foremost amongst these are the competing lens for the evolutionary processes, the appropriate and evolving geographic scope and boundaries of the ecosystem, and the evolving visible or invisible modes of governance. Methodologically, we call for greater use of longitudinal studies of such evolutionary processes.
\end{abstract}

Keywords Entrepreneurial ecosystem · Evolution . Governance $\cdot$ Adaptive $\cdot$ Lifecycle $\cdot$ Longitudinal . Review

D. S. Cho $(\bowtie) \cdot$ P. Ryan · G. Buciuni

Trinity Business School, Trinity College Dublin, Dublin 2, Ireland e-mail: chos@tcd.ie

P. Ryan

e-mail: paul.ryan@tcd.ie

G. Buciuni

e-mail: buciunig@tcd.ie
JEL Classifications F23 - L21 - L23 - L25 - L26 - L53 · $\mathrm{L} 6 \cdot \mathrm{M} 11 \cdot \mathrm{M} 13 \cdot \mathrm{M} 16 \cdot \mathrm{M} 20 \cdot \mathrm{O} 11 \cdot \mathrm{O} 25 \cdot \mathrm{O} 32 \cdot \mathrm{O} 36$. $\mathrm{R} 1 \cdot \mathrm{R} 58$

Plain English Summary Entrepreneurial ecosystems are by their nature evolutionary, a consideration surprisingly under-emphasized in a burgeoning literature. The allure of entrepreneurial ecosystems' potential has captured the interest of a broad swathe of researchers across a variety of fields, and policymakers hankering after the elixir for local economic growth. But with the increased volume of literature has come a fragmentation in the field that has shifted the research agenda away from its core foci in building a theory with concrete policy utility. To recover territory, we conduct a systematic literature review that first illustrates this exponential growth in the EE literature and some fragmentation. We then employ thematic analysis to create four fundamental categories that constitute the underpinnings of the EE concept: place, actors, governance, and evolution. Of these the least explored is the evolutionary dynamics and processes. We advocate for a greater emphasis by researchers on these evolutionary dynamics of the EE and present a roadmap for future research across multiplex dimensions of these processual phenomena.

\section{Introduction}

Successful local economies continuously refine and reshape their knowledge base and technological 
boundaries to preserve their competitiveness over time (Buciuni \& Pisano, 2018). This has emerged as an essential condition for their future prosperity and longterm sustainability. Others that fail to 'reinvent' themselves may fall into what Krugman refers to as the 'specialization trap'. Excessive specializing in a narrow set of economic activities is deemed detrimental to the long-term competitiveness of a mature regional economy (Hassink \& Shin, 2005; Narula, 2002; Williams \& Vorley, 2014) as this makes them vulnerable to others' comparative advantages. To survive and prosper, mature local economies have been left with little option but to evade the 'specialization trap' through relentless evolution to become productively active in new related or unrelated technological domains (Boschma, 2015; Kedron et al., 2019; Klepper, 2002; Kogler, 2015; Martin \& Sunley, 2015; Murmann \& Frenken, 2006). The evolution of an economic system hinges on its ability to absorb and develop a heterogeneous set of competences which serve as the foundations of economic complexity (Hidalgo \& Hausmann, 2009). By adding new forms of knowledge to the existing base of competences, regional economies can improve their economic complexity, expand in new technological and industrial spaces, and ultimately increase their likelihood of evading the 'specialization trap'.

In recent years, the ability of a territory to evade technology ensnarement and adapt to the vicissitudes of the global economy has found support in the emerging form of entrepreneurial ecosystems (Acs et al., 2017; Acs et al., 2014; Autio et al., 2014; Isenberg, 2010; O'Connor et al., 2018; Spigel, 2017; Stam \& Spigel, 2016). Entrepreneurial ecosystems are considered by some to be neither industry nor technology-specific (Auerswald \& Dani, 2017; Autio et al., 2018); in fact, their sustainability and evolution hinges on agnostic heterogeneity (Autio et al., 2018). Entrepreneurial ecosystems thinking is founded on the assumption that entrepreneurs are responsible for pushing the boundaries of a given economic system towards new geographical and technological trajectories. Entrepreneurs represent the aggregators and codifiers of new knowledge and competences, the triggers and enablers of innovation development, and the architects of new introductions into the market (Schumpeter, 1911; Shane \& Venkataraman, 2000).

Entrepreneurial ecosystems are by their nature dynamic and evolutionary, having an origin or antecedent and transitioning over time (Spigel \& Harrison, 2018).
Firms, industries. or even clusters within a local economy are subject to the finite nature of life cycles and eventual demise. For ecosystems, however, expiration is not inevitable. Rather, the evolutionary processes of adaptation and mutation induce the diversity and heterogeneity that facilitates the sustainability and perpetuity of an ecosystem (Malecki, 2018; Roundy, 2017). However, there is scant knowledge of how these evolutionary processes of entrepreneurial ecosystems are manifest (Alvedalen \& Boschma, 2017; Cavallo et al., 2019; Spigel \& Harrison, 2018). From its conception (Cohen, 2006), the academic literature on entrepreneurial ecosystems makes an implicit acknowledgement of the evolutionary imperative (Motoyama \& Knowlton, 2017; Pitelis, 2012). However, explicit studies of the evolution of entrepreneurial ecosystems are rare, or better considered more as expositions of industrial clusters' life cycles (Cantner et al., 2020; Mack \& Mayer, 2016). Much remains to be known about the antecedents and dynamics underlying the birth and evolution of local economies in the guise of complex entrepreneurial ecosystems.

As is common with emerging fields that exhibit early promise, a slow start to research on entrepreneurial ecosystems initially was then followed by a great upsurge in research output, in this case, triggered by a critical published piece that attracted wide attention (Isenberg, 2010). Academic researchers across a variety of fields and policymakers seeking the elixir of entrepreneur-led local economic growth turned their attention to the EE concept. Over a short number of years there emerged an enlarged volume of output then became cluttered and veered down unhelpful research alleys that inhibited theory development. Fragmentation and diffusion of research away from the core principles mitigated against theorizing. We propose that there is now the need for entrepreneurial ecosystems' literature development to take stock, re-categorize the research to date, and get back on track through a re-focus on the key tenets of the framework. For instance, we contend that some entrepreneurial ecosystems research has by parts become at extremes either overly narrow (universities and accelerators as entrepreneurial ecosystems) or excessively broad (entrepreneurial ecosystems on a global scale via digitalization) thereby hampering theory development. Recently there have been a number of systematic literature reviews on entrepreneurial ecosystems that have endeavoured to refine and shape the emerging field and provide directions for future research in the 
quest for a more general theory (Alvedalen \& Boschma, 2017; Brown \& Mason, 2017; Cao \& Shi, 2020; Cavallo et al., 2019; Hakala et al., 2020; Malecki, 2018; Stam \& Spigel, 2016) (see Table 1). Despite some inconsistencies in measurement, all show similar patterns of exponential growth in EE literature post-2015. However, there is no review article specifically on the evolution of entrepreneurial ecosystems to date.

Our aim, therefore, in this paper, is to reflect on and assess developments to date in the furtherance of the still under-theorized concept of entrepreneurial ecosystems. We in particular advocate for increased emphasis by researchers on the evolutionary dynamics and processes integral to the understanding of entrepreneurial ecosystems. To that end, we suggest in this paper that a number of crucial evolutionary aspects remain unresolved for entrepreneurial ecosystems. Foremost amongst these are the appropriate and evolving boundaries of the ecosystem, the internal and external sources of new knowledge and the actors blending them with the existing knowledge base, and whether the entrepreneurial ecosystem's evolution is guided by the visible hand of Government or is it less visibly anchored by large corporations, often MNEs, or institutions such as local universities. Additionally, shedding light on the intersection between local and global knowledge circuits will be a fundamental element of a new effective research approach. We frame the future research agenda around critical debates in need of further resolution: (1) entrepreneurial ecosystems as life cycle versus complex adaptive systems; (2) evolving boundaries of entrepreneurial ecosystems; and (3) governance of evolutionary entrepreneurial ecosystems. Additional to theory development considerations, there are methodological considerations for future research on the evolution of entrepreneurial ecosystems. It has been reported that much research to date consists of static, cross-sectional studies that miss out on crucial temporal change dynamics of entrepreneurial ecosystems across time (Adams, 2020; Alvedalen \& Boschma, 2017). There have been negligible systematic attempts at investigating the evolution of entrepreneurial ecosystems through a longitudinal analysis (Ryan et al., 2020). We, therefore, make some recommendations for longitudinal process approaches to future research more befitting of the study of evolutionary processes of entrepreneurial ecosystems.

In addition to advancing the heterogeneous and yet growing literature on entrepreneurial ecosystems, our work also carries important policy implications. Firstly, we contend that understanding the key mechanisms underpinning the evolution of entrepreneurial ecosystems will offer some valuable insights to policymakers focusing on fostering the competitiveness of regions and cities. Particularly in today's highly volatile global economy, understanding when and why ecosystems evolve over time and across space represents an essential starting point for any entrepreneurship- and innovation-focused policy. Secondly, tracking the evolution of entrepreneurial activities at local level will offer policymakers the opportunity to gauge the evolutionary trajectory of firms' specialization and sources of competitive advantage. This, we argue, will allow a finer-grained analysis of the specific requirements marking entrepreneurial firms' operational activity and the related areas of policy intervention like investments in the local educational systems, logistical infrastructures, and financial support. Finally, and building on the previous implication, a more explicit longitudinal analysis of entrepreneurial ecosystems will permit local institutions to scout outside the ecosystem for complementary resources. From the deployment of policies aimed at attracting foreign direct investments, to the creation of global pipelines to tap into relevant sources of knowledge and capital, we contend that a thorough understanding of the historic evolution of a local ecosystem will represent the necessary starting point for any outward-looking industrial policy.

The structure of the paper is as follows. The next section of the paper focuses on a systematic literature review. Section 3 develops a theory on evolutionary entrepreneurial ecosystems and illustrates some shortcomings inhibiting the emergence of a general theory. Section 4 addresses issues under debate and endeavours to shape a future research agenda and calls for the deployment of more apt methods. The final section presents a discussion and some early conclusions.

\section{Systematic literature review}

The conduct of our systematic review was influenced by robust exemplars of best practice previously published in Small Business Economics (Dabić et al., 2019; Grégoire \& Cherchem, 2020; Karami et al., 2019; Pittaway \& Cope, 2007). Guided by such, our systematic review broadly involved three stages: in the first, we systematically identified, collated, and filtered the existing EE literature to create a study population of 
Table 1 Review on entrepreneurial ecosystem

\begin{tabular}{|c|c|c|c|}
\hline Authors (year) & Type & Elements of EE & Future research/shortcomings of EE \\
\hline $\begin{array}{l}\text { Stam and Spigel } \\
\text { (2016) }\end{array}$ & Descriptive & $\begin{array}{l}\text { Attributes of EE } \\
\text { 1) Cultural } \\
\text { 2) Social: network, talent, capital, } \\
\text { etc. } \\
\text { 3) Material: infra, uni, policy, } \\
\text { services }\end{array}$ & $\begin{array}{l}<\text { Model }> \\
\text { EE elements (conditions) produces entrepreneurial activity } \\
\quad \text { (outcome) that leads to aggregate value creation (outcomes) }\end{array}$ \\
\hline $\begin{array}{l}\text { Alvedalen and } \\
\text { Boschma } \\
\text { (2017) }\end{array}$ & Descriptive & $\begin{array}{l}\text { Dynamic network framework } \\
\text { 1) Focus on institutional change } \\
\text { 2) Micro-level analysis on region, } \\
\text { actors, etc. } \\
\text { 3) Emphasis on the institution that } \\
\text { blocks dynamic EE } \\
\text { 4) Evolutionary perspective is } \\
\text { missing }\end{array}$ & $\begin{array}{l}\text { 1) Comparative research on networks } \\
\text { 2) EE's perception of different networks (knowledge, political) } \\
\text { 3) Institutional entrepreneurship (conditions for EE formation) }\end{array}$ \\
\hline $\begin{array}{l}\text { Brown and } \\
\text { Mason (2017) }\end{array}$ & Critical & $\begin{array}{l}\text { 1) Actors: support } \\
\text { 2) Connectors: professional service, } \\
\text { enterprise centres, etc. } \\
\text { 3) Resource providers: banks, VC, } \\
\text { etc. } \\
\text { 4) Entrepreneurial orientation: role } \\
\text { model, education, etc. }\end{array}$ & $\begin{array}{l}\text { 1) Scale-up ecosystem } \\
\text { 2) Dealmakers - social capital, mediators } \\
\text { 3) Block-buster entrepreneurship: high-growth and potential } \\
\text { 4) Entrepreneurial recycling (serial entrepreneurship) }\end{array}$ \\
\hline $\begin{array}{l}\text { Cavallo et al. } \\
\text { (2019) }\end{array}$ & Bibliometric & $\begin{array}{l}\text { 1) EE emphasize the complexity and } \\
\text { non-linearity of entrepreneurship } \\
\text { 2) Focus change: economic actors } \rightarrow \\
\text { culture within the EE } \\
\text { 3) Evolutionary aspect of EE is } \\
\text { lacking } \\
\text { 4) Context and temporal aspect is key } \\
\text { to EE }\end{array}$ & $\begin{array}{l}\text { 1) Entre. dynamics and governance } \\
\text { 2) Analysis of sub-systems of wider EE } \\
\text { 3) Focus on innovative and growth-oriented entrepreneurship } \\
\text { 4) Focus on specific territory }\end{array}$ \\
\hline Malecki (2018) & Bibliometric & $\begin{array}{l}\text { 1) EE is spatial and centrally local } \\
\text { 2) University-centred EE } \\
\text { 3) Evolution of EE - lifecycle } \\
\text { (scale-up) }\end{array}$ & $\begin{array}{l}\text { 1) Longitudinal study } \\
\text { 2) Network-based research } \\
\text { 3) Identify spinoff firms } \\
\text { 4) Narrative accounts } \\
\text { 5) Investigation of the EE elements } \\
\text { 6) Women entrepreneurs and EE }\end{array}$ \\
\hline $\begin{array}{l}\text { Hakala et al. } \\
\qquad(2020)\end{array}$ & $\begin{array}{l}\text { Review } \\
\text { method }\end{array}$ & $\begin{array}{l}\text { Proposed review method } \\
\text { 1) Thematic: themes, questions } \\
\text { 2) Enstoried: plot, narrative, } \\
\text { characters, voices, moral lesson } \\
\text { 3) Rhetorical reading: rhetoric } \\
\text { device, rhetorical strategy }\end{array}$ & $\begin{array}{l}\text { Model narrative of EE } \\
\text { 1) Concentration, clusters, locality, etc. } \\
\text { 2) Regional actors create EE and lead, produces only winners, the } \\
\text { system may lack governance, the interaction of the elements } \\
\text { 3) Govern to create the ecosystem }\end{array}$ \\
\hline $\begin{array}{l}\text { Cao and Shi } \\
\text { (2020) }\end{array}$ & Systematic & $\begin{array}{l}\text { A. EE elements } \\
\text { 1) Logic - structural interaction sys- } \\
\text { tem } \\
\text { 2) Resource - resource allocation } \\
\text { system } \\
\text { 3) Governance - ecosystem policy } \\
\text { approach } \\
\text { B. EE in emerging economies } \\
\text { 1) Institutional voids } \\
\text { 2) Resource scarcities } \\
\text { 3) Structural gaps }\end{array}$ & $\begin{array}{l}\text { 1) Digital affordances and EE apply to advanced economy can } \\
\text { enable delocalization } \\
\text { 2) Entre culture can be the result rather than a driver } \\
\text { 3) Distinctiveness of EE and the related concept has not been } \\
\text { discussed substantially } \\
\text { 4) Reliance on government-led EE needs to be reduced }\end{array}$ \\
\hline
\end{tabular}

top quality journal articles. We then proceeded to categorize these articles into four themes that have to date served as the main foci of the entrepreneurial ecosystem literature. We lastly showed that of these four themes, 
the literature on evolutionary dynamics and processes of entrepreneurial ecosystems has been least explored.

Stage one of our systematic review process followed the method proposed by Tranfield et al. (2003): (1) a detailed planning of the review process around search terms; and (2) a staged filtering of the collated literature via a rigorous filtration process for inclusion and exclusion; and (3) a detailed deep-grained analysis of the selected literature. For the first planning step, we defined the conceptual boundaries and screening criteria such as publication type and objective research quality via the widely recognized ABS classification system. As the initial academic paper on EE was published in 2006, we conducted the search for publications between 2006 and 2020. Based on these screening considerations and decisions, we then assembled the EE literature through the conduct of an extensive literature string search of various databases, including ProQuest, Scopus, Web of Science (WoS), and Business Source Complete (BSC). The search strings used were 'Entrepreneur* Ecosystem*'. The first wave search included published and unpublished materials such as journal articles, working papers, conferences proceedings, and papers in an edited volume (Mochkabadi \& Volkmann, 2020). Our initial filtration process only included scientific publications with a definite abstract. Therefore, publications such as books, book chapters, reports, and editorials were excluded (Liñán \& Fayolle, 2015). This initial search and filtration, combined with the cleansing and eliminating of duplicates, recovered 2697 articles. We then screened these filtered set of papers by analysing the content of the title and abstract to ensure it was explicitly related to EE. Post this second round filtration process, we identified 568 relevant contributions on EE in all journals of the broadest quality. Figure 1 shows that after the initial use of the term 'entrepreneurial ecosystem' in the publication of Cohen (2006), EE published research output showed no pattern of increase for almost a decade. The publication in HBR of Isenberg's (2010) policy advisory steps triggered stronger interest amongst academics. Consequently, output sharply increased from the year 2015 . Of the twice filtered 568 articles, 387 were found to be in the ABS listing, and, of these, 137 were top-ranked classed as ABS 3, 4, or 4*. Figure 2 shows EE research has been published in leading journals such as Entrepreneurship Theory \& Practice, Research Policy, Small Business Economics, Entrepreneurship and Regional Development, and Regional Studies. This list represents an interesting mix of Entrepreneurship and Economic
Geography journals. This final number of 137 journal articles constituted our final study population for subsequent thematic analysis and categorization.

The co-authors now reviewed and analysed these 137 higher ranked articles following Braun and Clarke's (2006) systematic procedure to identify the principal themes within the EE literature published to date. From our deep understanding of the EE literature and assiduous reading of population articles, we identified themes based on our agreed categorization and classification of our population of publications. Any discrepancies in theme identification were discussed by the co-authors and minor adjustments applied where deemed necessary. If a publication addressed multiple themes, the stated aim of the study served as our criterion for categorization and classification (Liñán \& Fayolle, 2015). Our analysis resulted in four predominant themes: Place, Governance, Actors, and Evolution (see Fig. 3). We readily established that the quantity of articles in three of the thematic categories, place, actors, and governance, heavily outnumbered those on evolution. There is clearly a distinct paucity of explicit studies on the evolution of entrepreneurial ecosystems. Of the 137 topranked articles, we have only identified 14 articles that can be deemed to have entrepreneurial ecosystem evolution as their prime focus of investigation (see Table 2). All of these have been published since 2016. Only nine of these are empirical and even these limited few have methodological dissonance having been widely reproached for a failure to extend beyond a static framework and attendant inability to capture evolutionary processes over time (Acs et al., 2017; Adams, 2020; Alvedalen \& Boschma, 2017; Cavallo et al., 2019; Stam, 2015). In Table 3, we identify merely 10 longitudinal studies in our population and only four of these (Auerswald \& Dani, 2017; Ryan et al., 2020; Schäfer \& Henn, 2018; Thompson et al., 2018) are also to be observed in the list of EE evolution studies. Previous EE review articles also point to the drawback of static studies and lack of dynamism and longitudinal methods and approaches, but tangentially and without much guidance for rectification and theoretical advancement (Alvedalen \& Boschma, 2017; Brown \& Mason, 2017; Malecki, 2018). Although some scholars have called for and placed increased emphasis on the temporality of EE through studies of evolutionary processes and governance across time (Colombo et al., 2019; Spigel \& Harrison, 2018), they still represent a significant minority. Therefore, to redress these deficiencies, we propose 
Fig. 1 Numbers of publication (ABS journals)

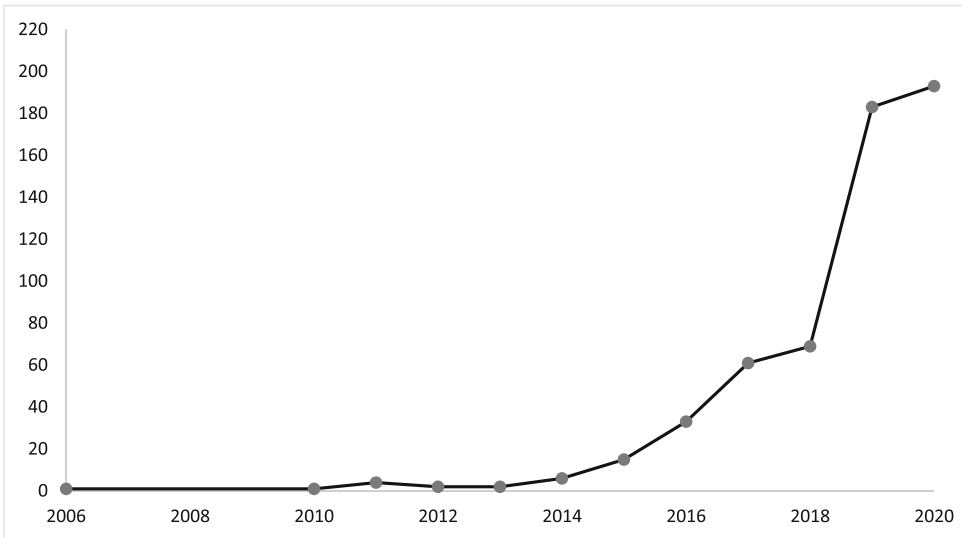

a research agenda for theory development that places a heavy emphasis on future studies to better and more comprehensively capture evolutionary processes of entrepreneurial ecosystems.

\section{An evolutionary perspective on entrepreneurial ecosystems}

The entrepreneurial ecosystem perspective represents a more holistic and finer-grained approach to studying the evolution of a local economy and its underlying mechanisms (Audretsch \& Belitski, 2017; Cohen, 2006; Isenberg, 2010; Stam, 2015; Stam \& Spigel, 2016; Stam \& van de Ven, 2019). An entrepreneurial ecosystem generally operates on a grander scale and scope than a conventional industrial cluster and is commonly industry and technology agnostic (Auerswald \& Dani, 2017; Autio et al., 2018; Malecki, 2018). Amongst the features that define the entrepreneurial ecosystem framework, the notion of sustainability has been at the core of this novel research discipline since its early developments (Cohen, 2006). An ecosystem's sustainability derives from the introduction of heterogeneous variation and adaptation that can extend an entrepreneurial ecosystem's lifespan (Boschma, 2015; Colombelli et al., 2019; Malecki, 2018; Roundy, 2017; Ryan et al., 2020; Spigel \& Harrison, 2018). As a result, the resilience and long-term competitiveness of an entrepreneurial ecosystem spring from coherency around specialism in its early existence (Roundy, 2017; Spigel \& Harrison, 2018) and heterogeneity from the later diversity introduced by new firm formations across multiple technologies (Malecki, 2018).

Much of the early work on entrepreneurial ecosystem research was policy-oriented aiming to develop economic growth prescriptions for and via expanded entrepreneurial activity (Cukier et al., 2015; Gauthier et al., 2017; Isenberg, 2011; Mason \& Brown, 2013, 2014; Mulas et al., 2016). Growth, by its very nature, implies
Fig. 2 Principal journal outlets (peer-reviewed)

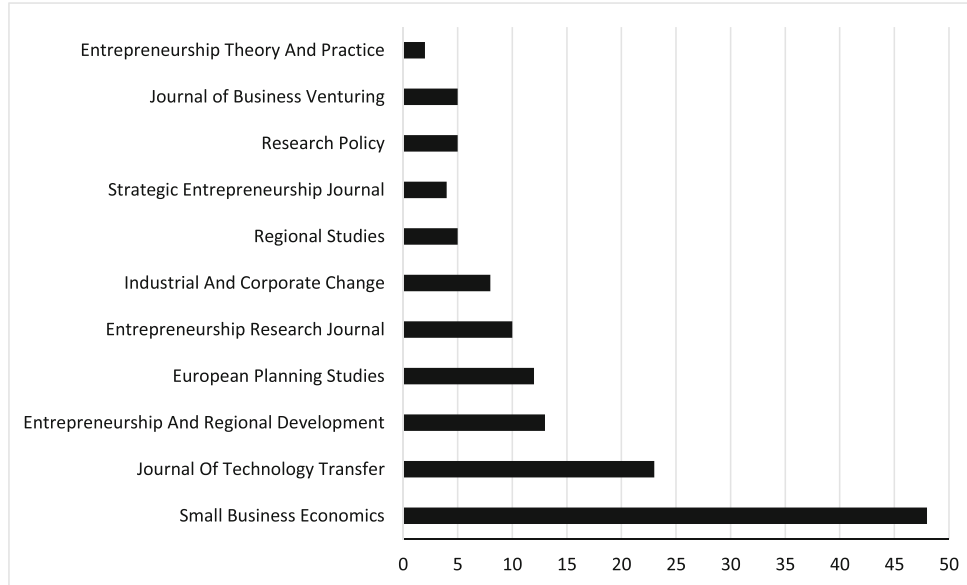


Fig. 3 Primary themes in EE literature (ABS 3 and above journals)

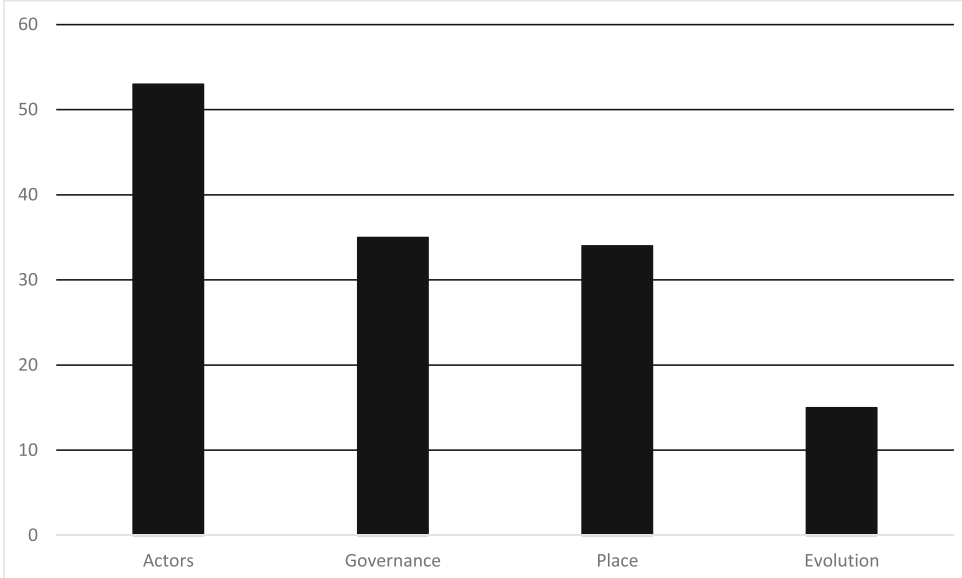

evolutionary processes. In a seminal and highly influential policy report, Mason and Brown (2014) presented an early evolutionary model of an entrepreneurial ecosystem. Building on this, a few years later the same authors developed their pilot policy work academically to propose a two-stage typology of nascence and maturity of entrepreneurial ecosystems distinguishing between early-stage 'embryonic' and later-stage 'scaleup' ecosystems (Brown \& Mason, 2017). Around the same time, and confirming the development of a new research pattern, Mack and Mayer (2016) pioneered an evolutionary model that dealt with EE dynamics over time. Colombelli et al. (2019) then used hierarchical and relational governance lenses to present the life cycle stages of entrepreneurial ecosystems as 'birth', 'transition', and 'consolidation'.

As the study of the evolution of EEs gained traction, further studies examined the origins and creation of an entrepreneurial ecosystem and the early stages of its existence (Harima et al., 2020; Roundy et al., 2018; Thompson et al., 2018); others then placed particular emphasis on the later maturity stages. Malecki (2018), for instance, describes the elements of an entrepreneurial ecosystem that matured into one deemed to be a 'strong' entrepreneurial ecosystem, and others depicted the composition of a matured 'resilient' version (Roundy, 2017; Ryan et al., 2020). For some researchers, however, the life cycle approach came to represent an inappropriate lens since the evolution of an entrepreneurial ecosystem was seen to be non-linear across stages, but rather, recursive as with an adaptive system (Adams, 2020; Auerswald \& Dani, 2017; Haarhaus et al., 2020; Roundy et al., 2018).

Existing studies also suggest that there are multiple evolutionary pathways for entrepreneurial ecosystems.
The creation and evolution of an entrepreneurial ecosystem can be organically entrepreneur-led (Feld, 2012); alternatively and possibly simultaneously, it can be guided by the visible hand of government (Adams, 2020; Fuerlinger et al., 2015), or even anchored by large corporations (Bhawe et al., 2019; Colombo et al., 2019; Ryan et al., 2020) and universities (Cunningham et al., 2019; Hayter, 2016; Johnson et al., 2019; Miller \& Acs, 2017; Nicholls-Nixon et al., 2020). Additionally, an entrepreneurial ecosystem can mutate from a pre-existing system such as an industry cluster (Autio et al., 2018; Pitelis, 2012), or set of co-located clusters of varying vintages, through technological convergence in related and unrelated branches (Auerswald \& Dani, 2017). For instance, Ryan et al. (2020) empirically illustrated how a strong, resilient entrepreneurial ecosystem could emerge from the metamorphosis of an antecedent industrial cluster, primarily via MNE spinouts, and lead the evolution of an entire production region. Contrariwise, Cantner et al. (2020) conceptually outlined subsequence for an entrepreneurial ecosystem in its further evolution into a 'business ecosystem'.

Regardless of the specific evolutionary path, an ecosystem can follow, incumbent entrepreneurs and corporate or institutional spillovers generally play a key role in the development of entrepreneurial ecosystems. Pioneer entrepreneurs that either serially start more firms or successfully exit their initial venture serve to activate an entrepreneurial ecosystem's ongoing growth and renewal. They do so as role models, mentors, and even angel financiers that channel their resources, time, and energy into its perpetuation (Mason \& Brown, 2014; Mason \& Harrison, 2006; Ryan et al., 2020). Spillovers can serve to propel and expand the evolution of an entrepreneurial 


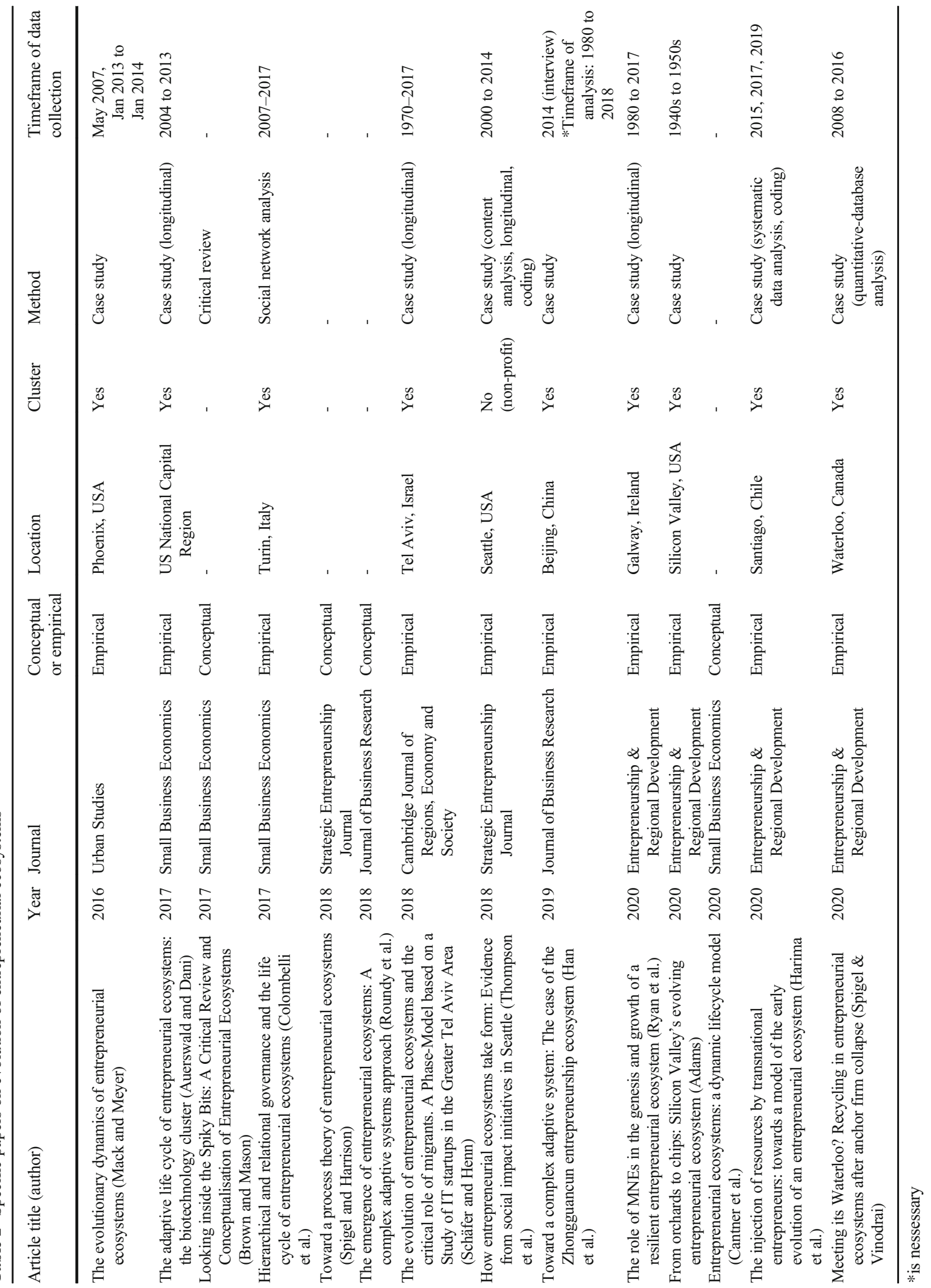


ecosystem, primarily by building on and expanding the accumulation of knowledge at a local level (Agrawal \& Cockburn, 2003; Breschi \& Lissoni, 2003; Clarysse et al., 2014; Harima et al., 2020; Ryan et al., 2020; Van De Ven, 1993). They generally come in either of two forms, spinout or spinoff.

Large enterprises, both indigenous and inward investors, can serve as the breeding grounds of local entrepreneurship in several domains. They can contribute and catalyse an entrepreneurial ecosystem's creation and growth by taking the role of incubators and stimulating the spinout of high-tech start-ups in related and unrelated varieties (Brown \& Mason, 2017; Colombelli et al., 2019; Klepper, 1996, 2007; Ryan et al., 2018; Spigel \& Harrison, 2018). Large firms attract skilled employees, enhance their managerial skills, and provide them with business opportunities by connecting them to global customers (Colombelli et al., 2019; Ryan et al., 2020). Employees' experiences and learnings in these large organizations are likely to spawn new spinout ventures mostly through the development of variants of a core product. Over time, this process increases heterogeneity in the entrepreneurial ecosystem, hence supporting its long-term competitiveness. Spinouts, in fact, fuel diversification and new knowledge creation and create heterogeneity that eventually strengthens the resilience of an entrepreneurial ecosystem. As such, large firms act as 'knowledge integrators' within the entrepreneurial ecosystem and facilitate the codification and absorption of new knowledge at the local level and provide connectivity to new global market opportunities for indigenous firms or aspiring entrepreneurs (Bhawe et al., 2019; Buciuni \& Pisano, 2018).

Large firms are not the only actors supporting the evolution of an entrepreneurial ecosystem. Universities can also deepen an entrepreneurial ecosystem's technology base and enhance its capacity as the breeding ground for entrepreneurship. Extensive research shows that universities can incubate and facilitate new venture spinoffs in an entrepreneurial ecosystem too (Cunningham et al., 2019; Hayter et al., 2018; Johnson et al., 2019; Miller \& Acs, 2017; Nicholls-Nixon et al., 2020; Theodoraki et al., 2018). Renowned entrepreneurial ecosystems, such as Silicon Valley, Route 158, and Cambridge UK, have world-class universities that record high rates of such spinoffs (Audretsch \& Belitski, 2013). These spinoff ventures are commonly in new technology domains either in related or unrelated varieties (Boschma \& Frenken, 2011; Meoli et al., 2019;
Meoli \& Vismara, 2016). This increased heterogeneity amplifies the resilience of the entrepreneurial ecosystem (Roundy, 2017).

\section{Debates and agenda for future evolutionary entrepreneurial ecosystem research}

There are areas of discord amongst the community of entrepreneurial ecosystem (EE) scholars that are in need of resolution to progress the entrepreneurial ecosystem from framework to theory. We now bring forth what we identify as some crucial debates and issues for resolution in the entrepreneurial ecosystem field and suggest specific areas for future research on the evolutionary processes rather than the more prevalent but issues such as EE elements and actors. These are both static and by now well-rehearsed.

4.1 Is the evolving EE more a life cycle or an adaptive system?

Our systematic review shows that of the few articles published on the evolution of EEs, most presented a life cycle stages model (Cantner et al., 2020; Colombelli et al., 2019; Mack \& Mayer, 2016; Thompson et al., 2018). But there are issues around this approach to mapping the evolution of entrepreneurial ecosystems. Mack and Mayer's (2016) original life cycle model culminates with dual pathways either of deathly expiration or, more positively, rebirth through recycling or renewal. This debate mirrors an earlier, largely unresolved one for cluster theory as to whether life cycles or adaptive systems represent more realistic versions of evolutionary processes (Martin \& Sunley, 2011). However, clusters can be finite and destroyed by technological disruptions (Narula, 2002). But, as the term 'ecosystem' prescribes, the ultimate aspiration for an entrepreneurial ecosystem is a continuing renewal (Malecki, 2018). A weak or 'failing' entrepreneurial ecosystem (Auerswald, 2015) is not equivalent to death and can be resuscitated. Failure can be overcome, and even serve as a learning experience building resilience. Rather than the disastrous pathway to expiration under the life cycle thesis, the aim in a strong entrepreneurial ecosystem is to avoid dwindling into decline, through engendering resilience and sustainability over time (Roundy, 2017). Therefore, despite the obvious appeal of the life cycle approach to the characterization of the evolution of an 
Table 3 Longitudinal studies on entrepreneurial ecosystems

\begin{tabular}{llll}
\hline Title (author, year, journal) & Research question & $\begin{array}{l}\text { Timeframe in } \\
\text { years }\end{array}$ & Data
\end{tabular}

The adaptive life cycle of
entrepreneurial ecosystems: the
biotechnology cluster
(Auerswald \& Dani, 2017,
SBE)
How entrepreneurial ecosystems
take form: Evidence from social
impact initiatives in Seattle
(Thompson et al., 2018, SEJ)

The evolution of entrepreneurial ecosystems and the critical role of migrants. A Phase-Model based on a Study of IT startups in the Greater Tel Aviv Area (Schäfer \& Henn, 2018, CJR)

Governance in entrepreneurial ecosystems: venture capitalists vs. technology parks (Cumming et al., 2019, SBE)

The creation of high-tech ventures in entrepreneurial ecosystems: exploring the interactions among university knowledge, cooperative banks, and individual attitudes (Ghio et al., 2019, SBE)

\footnotetext{
Entrepreneurial ecosystem conditions and gendered national-level entrepreneurial activity: a 14-year panel study of GEM (Hechavarría \& Ingram, 2019, SBE)

Regional entrepreneurial ecosystems in China (Lai \& Vonortas, 2019, ICC)
}

What is the role of
entrepreneurship in developing essential capabilities and networks that drive the sustainable development of regions? (p. 112)

How entrepreneurial form in the field of social enterprise? ecosystems linked to geographically distant entrepreneurial ecosystems and how the linkages between such systems affect regional entrepreneurial performance?

What types of start-ups (VC backed or technology parks) achieve an acquisition?

How does local availability of university knowledge interact with the relative presence of cooperative banks in the local banking industry and with the residents' tendency to behave opportunistically to determine the creation of high-tech ventures in a territory?

Does the entrepreneurial ecosystem influence the prevalence of male and female entrepreneurship over time?

What is the model capturing systemic factors that explain regional variation in important facets of entrepreneurship in one important emerging economy, China?

\section{4-2013 \\ National Capital \\ Region's \\ biotechnology \\ cluster \\ 2012-2014 \\ (Social impact business EE, Seattle, USA)}

1970-2017

Greater Tel-Aviv Area high-tech cluster

\section{7-2014 \\ (251 software companies in the USA)}

2012-2014

(792 high-tech firms created in the Italian provinces)

2008-2015

(263 Chinese prefecture-level municipalities) (out of a total of 334 in the country)

\section{1-2014 \\ (403 cases and 75 countries)}

The buzz before business: a design How entrepreneurial opportunities science study of a sustainable entrepreneurial ecosystem (O'Shea et al., 2019, SBE)

co-evolve within a sustainable entrepreneurship ecosystem (SEE)?
2015-2016

(Helsinki, Finland)
Cluster

Database

ACS 2013 - 5-year estimates, National Science Foundation, Inc 5000 2015, Web of Science

Interview (structured), public records, news outlets, webpages, documents

Threads of social impact enterprises

Database: IVC Research Center, US Homeland Security, Startup Nation Finder

Interview

Panel data

Cumulative incidence function (CIF)

Database

Crunchbase com

Panel data

Database: Italian Ministry of Education Research (MIUR), Bank of Italy statistical office, Bank of Italy, Thompson One; Venture Capital Monitor, ISTAT, CRIOS-PATSTAT

Panel data

Database: World Bank

Development Indicators,

Global Entrepreneurship Monitor Adult Population Survey and National Expert Survey

Panel and survey data

Database: National Company Credit Information System (NCCIS), Sixth National Population Census, Province Intellectual Property office, Higher Education Statistical Survey, Asset Management Association, China city yearbook, CSMAR

Exploratory (semi-structured) interviews, coding

Case: Sustainable cellulose ecosystem project
Quantitative (comparison between the cluster and USA)

Qualitative case (multiple) (content and longitudinal analysis, coding)

Qualitative case (longitudinal process)

Quantitative (regression)

Quantitative (econometric modelling zero-inflated binominal specification)

Quantitative (survey, autoregressive distributed lagged models)

Quantitative (econometric analysis)

Qualitative single case study (SCEP) multi-stage longitudinal process 
Table 3 (continued)

\begin{tabular}{|c|c|c|c|c|}
\hline Title (author, year, journal) & Research question & $\begin{array}{l}\text { Timeframe in } \\
\text { years }\end{array}$ & Data & Method \\
\hline $\begin{array}{l}\text { Gimme shelter or fade away: The } \\
\text { impact of regional } \\
\text { entrepreneurial ecosystem } \\
\text { quality on venture survival } \\
\text { (Vedula \& Kim, 2019, ICC) }\end{array}$ & $\begin{array}{l}\text { To what extent does the quality of } \\
\text { a region's entrepreneurial } \\
\text { ecosystem matter for venture } \\
\text { survival? }\end{array}$ & $\begin{array}{l}\text { 2004-2011 } \\
\text { (301 US } \\
\text { Metropolitan } \\
\text { Statistical } \\
\text { Areas) }\end{array}$ & $\begin{array}{l}\text { Survey, panel data } \\
\text { Database: Kauffman Firm Survey } \\
\text { (KFS), US Census Bureau, } \\
\text { Thomson Reuters } \\
\text { VenturExpert, Small Business } \\
\text { Administration and Federal } \\
\text { Deposit Insurance Corporation, } \\
\text { US Patent and Trademark } \\
\text { Office, National Business } \\
\text { Incubator Association, } \\
\text { Seed-Db.com, National Center } \\
\text { for Educational Statistics }\end{array}$ & $\begin{array}{l}\text { Quantitative } \\
\text { (semiparametr- } \\
\text { ic Cox hazard } \\
\text { regression } \\
\text { model) }\end{array}$ \\
\hline $\begin{array}{l}\text { The role of MNEs in the genesis } \\
\text { and growth of a resilient } \\
\text { entrepreneurial ecosystem } \\
\text { (Ryan et al., 2020, E\&RD) }\end{array}$ & $\begin{array}{l}\text { How do MNEs generate } \\
\text { entrepreneurship and shape the } \\
\text { form of innovation trajectories } \\
\text { that can evolve in an } \\
\text { entrepreneurial ecosystem over } \\
\text { time? }\end{array}$ & $\begin{array}{l}\text { 1980-2017 } \\
\text { (Galway medical } \\
\quad \text { cluster) }\end{array}$ & $\begin{array}{l}51 \text { in-depth interviews } \\
\text { Data: European Patent Office } \\
\text { (EPO) PATSTAT, Irish Com- } \\
\text { pany Registration Office, } \\
\text { FAME, newspaper, websites, } \\
\text { LinkedIn }\end{array}$ & $\begin{array}{l}\text { Qualitative } \\
\text { multi-level } \\
\text { longitudinal } \\
\text { process study } \\
\text { + Quantitative } \\
\text { data }\end{array}$ \\
\hline
\end{tabular}

*Sources: authors

*Journal abbreviations: SBE, Small Business Economics; SEJ, Strategic Entrepreneurship Journal; CJR, Cambridge Journal of Regions, Economy and Society; $I C C$, Industrial and Corporate Change; $E \& R D$, Entrepreneurship and Regional Development

entrepreneurial ecosystem (Malecki, 2018), for some researchers, the life cycle represents an inappropriate lens since the evolution of an entrepreneurial ecosystem is not linear across stages but rather recursive as with an adaptive system (Adams, 2020; Auerswald \& Dani, 2017; Roundy et al., 2018). Some entrepreneurial ecosystem research distinguishes between the life-cycle aspect of the cluster and the complex adaptive system of evolutionary entrepreneurial ecosystem (Kuratko et al., 2015). Future research can address which approach has more merit.

Further, and extending the adaptive systems debate, as with all economic systems and production regions, a debate on entrepreneurial ecosystems persists as to whether their birth and evolution is a natural process, a form of 'panarchy' (Holling \& Gunderson, 2002), or artificially man-made (Hannan \& Freeman, 1989; Schumpeter, 1911). But this debate is magnified in the entrepreneurial ecosystem context given its underpinning of a natural analogy in the ecosystem. The entrepreneurial ecosystem approach is linked to ecological concepts. This debate is even more strident for entrepreneurial ecosystems given the central focus on 'ecosystem' which is borrowed from the natural world as distinct from industrial districts or regional innovation systems. The relation and application of ecosystem in the natural world to entrepreneurial ecosystem is wellrehearsed (Auerswald, 2015). However, Colombelli et al. (2019) nevertheless query the extent to which it is artificially guided and governed. Also, Acs et al. (2017) argue against the non-nuanced applicability of the ecosystem analogy from natural sciences as it (naturally) differs from that of economic agents that interact within their environment. The ecological/ biological view supports the structure and relationships in the ecosystem. Ecosystems are geographically bound with mutually dependent parts (Napier \& Hansen, 2011). A natural ecosystem is based on Darwinist evolutionary issues of diversity, selection, diversification, adaptation, resilience, and strength (Boschma, 2015). Moore (1993) was the first scholar to adopt the term 'ecosystem' in the fields of business and management. For Moore, the evolution in the business ecosystem derives from the 'original swirl of capital, customer interest, and talent generated by innovation, just as successful species spring from the natural resources of sunlight, water, and soil nutrients' (Moore, 1993, P.76). Further research can usefully evaluate the extent to which the evolution of entrepreneurial ecosystems is a result of nature or nurture, or some hybrid?

But the less clear cut on the superiority of the adaptive cycle approach with its recursive essence is how to 
establish the original creation of an entrepreneurial ecosystem (Cantner et al., 2020; Harima et al., 2020; Mack \& Mayer, 2016; Roundy et al., 2018; Ryan et al., 2020; Thompson et al., 2018). Different actors can impact the birth and growth of an entrepreneurial ecosystem. Examples of EE catalysts include the local university (Cunningham et al., 2019; Hayter et al., 2018; Johnson et al., 2019; Miller \& Acs, 2017; Nicholls-Nixon et al., 2020), incubators and accelerators (Breznitz \& Zhang, 2019; Hochberg, 2016; Qin et al., 2019), diaspora (Baron \& Harima, 2019; Schäfer \& Henn, 2018), and large firms (Bhawe \& Zahra, 2019; Colombo et al., 2019; Mason, Colin; Brown 2014; Ryan et al., 2020). Future research could address the roles of actors in the creation of an entrepreneurial ecosystem. Then, examine if the same actors govern its growth, consolidation, even disruption?

Ultimately, an entrepreneurial ecosystem is an evolutionary system that links actors in a place within a governance structure. The relativities of importance shift over time and with that comes evolving emphases on priorities. Which aspects matter at different stages of evolution and how the elements interact within the ecosystem over time is an avenue of interest for research on system and network dynamics. Case research can usefully identify idiosyncratic depictions of interrelations across evolution of an entrepreneurial ecosystem.

Large, often anchor, firms have been shown to profoundly affect the evolution of an EE (Buenstorf \& Klepper, 2009; Feldman, 2003; Giblin \& Ryan, 2012; Ryan et al., 2020). But further explanation is needed on how entrepreneurial activity is incubated, nurtured, and expanded in and by these large firms. These large firms can be inward investing MNEs (Bhawe \& Zahra, 2019; Ryan et al., 2020) that may incubate (Acs et al., 2013; Ryan et al., 2020) or squeeze out entrepreneurship in a local economy (Audretsch \& Keilbach, 2008; Berrill et al., 2020; De Backer \& Sleuwaegen, 2003). Future research could explore the balance of benefits versus drawbacks of FDI in entrepreneurial ecosystem creation and evolutionary growth and strength.

\subsection{What are the evolving boundaries and different} models of entrepreneurial ecosystems?

Some notable scholars in the field of economic geography and systems of entrepreneurship have set out the context of entrepreneurial systems as national wherein entrepreneurs drive the system and institutions support and regulate their actions (Acs et al., 2014).
Conventionally in the literature, however, an entrepreneurial ecosystem is rooted in place with a relatively distinct local or regional geographic boundary within which is contained mutually dependent components (Adams, 2020; Auerswald, 2015; Brown \& Mason, 2017; Mason \& Brown, 2014; O'Connor et al., 2018; Stam, 2015). These have dynamic evolutionary processes of selection, variety, and adaptation (Boschma, 2015; Malecki, 2018; Roundy et al., 2018). Bounded dynamic entrepreneurial activity encompasses local culture, the decision-making, firms' growth, and individual traits (Audretsch \& Belitski, 2017; Feldman \& Kogler, 2010). From an evolutionary perspective, the essence of place can change over time as boundaries may shift and scale expands. Recently, scholars have considered the challenges and nuances for entrepreneurial ecosystems and localness in the digital age (Song, 2019; Sussan \& Acs, 2017). They propose that local context may be constraining since digitization not only pays little or no respect to local boundaries but affords greater opportunities to entrepreneurs within a virtual scaffolding (Autio et al., 2018). In this view, EE research would no longer be in the purview of regional development. Research may consider it an expanded form of entrepreneurial ecosystem beyond local or a new category for the global scale for systems of entrepreneurship.

In the economic geography and IB fields, even under conditions of localness, global connectivity has been shown to be important for the success of local economies under the auspices of modern globalization (Mudambi et al., 2017; Perri et al., 2017). The successful local ecosystem hinges on the global economy and draws new knowledge from a variety of sources often situated outside its geographical boundaries. This allows the ecosystem to avoid 'cognitive myopia', a condition that has caused the demise of numerous traditional industrial clusters (Buciuni \& Pisano, 2018). Furthermore, a globally connected EE can serve as a global pipeline for entrepreneurs in the region and encourage the development of innovation in related and unrelated technological domains. Critical to this process is the ability of entrepreneurs to mix global market knowledge and local production and technical expertise in the attempt to generate new product and process innovation. Building on this phenomenon, it will be useful for future research to understand the external mechanisms that enable valuable resources and knowledge to flow into, and out of the ecosystem, thereby promoting its evolution and continued sustenance. 
Assessing the mechanisms whereby an ecosystem's boundaries evolve over time and across space requires understanding the meaning of the geographical scope of such boundaries. If the digitized global scale for an EE is too large, then, at the other extreme, viewing universities and accelerators, not as actors or elements but rather as EEs in their own right is confusingly too small and restricting (Johnson et al., 2019; Nicholls-Nixon et al., 2020; Qin et al., 2019). Future research should focus on the region as the unit of study but can also consider 'nested' subset ecosystems. In addition, further research should be dedicated to explore the relationship between entrepreneurial ecosystems and industrial clusters, with a specific focus on the intersections and overlaps between these distinct frameworks. Although the entrepreneurial ecosystem concept is broader in scope (cross or beyond industry) than individual industry clusters (Auerswald \& Dani, 2017; Autio et al., 2018), future investigations into entrepreneurial ecosystems could usefully embrace firms operating in a variety of co-located industry clusters (Stam \& Spigel, 2016) to assess their interdependence and its impact on a region's competitiveness. Building on this, future research should better match entrepreneurial ecosystems to local economies, investigate the relationships existing between these two concepts, and analyse how the geographical boundaries of the two can change over time and across space.

Understanding the nature and the dynamics underpinning the evolution of entrepreneurial ecosystems will also allow us to shed greater light on different models and typologies of ecosystems that can take shape over time and across space. To date, in fact, there has not been any significant attempt at understanding whether different typologies of entrepreneurial ecosystems may coexist, how they differ from one another, and what are the key characteristics marking each possible typology. As the literature on entrepreneurial ecosystems keeps expanding rapidly, an evolutionary perspective on this very topic can inform scholars researching in this field on the different trajectories that different ecosystems can follow over time. Clustering ecosystems into different categories could therefore help provide a better understanding of how entrepreneurial ecosystems work and how they change over time, and what implications their evolution carries for policymakers, scholars, and entrepreneurs alike. Building on the work of Markusen (1996) on the plurality of industrial districts, and more recently, that of Buciuni and Pisano (2021) on the variety of architectures in global value chains (GVCs), we call for future research that can examine the existence of different models of entrepreneurial ecosystems.

\subsection{Governance of evolutionary entrepreneurial ecosystems}

Governance of an entrepreneurial ecosystem's evolution has two potential approaches, invisible (bottom-up) and visible (top-down) (Colombo et al., 2019). The bottomup school suggests that rather than being spawned by visible government, corporations, or institutions, entrepreneurial ecosystem evolution should be entrepreneurled (invisible hand) (Auerswald, 2015; Feld, 2012; Isenberg, 2010; Kuckertz, 2019; Mason \& Brown, 2014). According to this view, the unique culture and dynamic network of actors creates a bottom-up and invisible governance in EE (Bosma et al., 2018). To what extent is the invisible hand at play or the guided visible hand predominant in evolution of entrepreneurial ecosystem? Some scholars warned not to take 'ecosystem' literarily since entrepreneurial ecosystem concept is 'artificial' in being human-made (Acs et al., 2013, 2017; Cantner et al., 2020; Mack \& Mayer, 2016; Roundy, 2017; Stam, 2015; Stam \& van de Ven, 2019; Stam \& Spigel, 2016). Alternatively, the visible hand of State (Adams, 2020; Fuerlinger et al., 2015) may be in evidence through supporting institutions and organizations, both public and private, that fund incubators and accelerators and provide mentorship for actors in the entrepreneurial ecosystem (Hochberg, 2016). Future research could usefully investigate which governance approach to evolutionary entrepreneurial ecosystem is more effective, naturalistic organic entrepreneurled or artificial structured Government-led? Besides this apparent dichotomy, the origin and evolution of EEs might, in fact, depend on both these factors. Instead of thinking of entrepreneur-led and government-led as two alternative options, scholars should investigate their interdependences and potential areas of convergence and examine how they impact on the long-term sustainability of an ecosystem.

4.4 Using methodology right: the need for longitudinal process studies of EE evolution

Surprisingly, most entrepreneurial ecosystem studies lack a 'time' dimension (Adams, 2020; Donegan et al., 2019). Methodologically, most research to date consists 
of cross-sectional studies that are static, and thus miss out on crucial temporal change dynamics of entrepreneurial ecosystem evolutionary processes across time (Adams, 2020; Alvedalen \& Boschma, 2017; Stam, 2015). An entrepreneurial ecosystem is in a perpetual process of development and evolution (Spigel \& Harrison, 2018). We contend that the explanation of how entrepreneurial ecosystems evolve over time and across space requires a longitudinal perspective to map and track these metamorphoses in the ecosystem from inception. To date, we identify only ten systematic attempts at assessing the evolution of entrepreneurial ecosystems through a longitudinal analysis (see Table 3). Even of these few, most could be questioned as to whether they are actually longitudinal or rather, retrospective investigations of historical panel set data. Only three are explicitly longitudinal in that data was collected in real-time over time (Ryan et al., 2020; Schäfer \& Henn, 2018; Thompson et al., 2018). We call for process studies of evolutionary processes of entrepreneurial ecosystems with extended time frames, often across temporal brackets (Langley, 2007; Pettigrew, 1990; Welch \& Paavilainen-Mäntymäki, 2014).

Lastly, this call for longitudinal process studies will mostly necessitate case studies of evolving or evolved entrepreneurial ecosystems. The evolutionary path of an entrepreneurial ecosystem is idiosyncratic, which impacts its theoretical utility. Even in one study, Spigel (2017) illustrates the divergent evolutionary paths of two entrepreneurial ecosystems, Waterloo and Calgary, that differ in their cultural, social, and material attributes. There are few prescriptions for the successful evolution of an entrepreneurial ecosystem. For example, even the most renowned of all entrepreneurial ecosystems, Silicon Valley, had its own distinctive origins and journey (Adams, 2020). Yet, learning from it did not represent a universal panacea for regional development across the world. This highlights the challenges for future research of theory building from multiple idiosyncratic cases. To meet this challenge, well-designed case studies are required that can be aggregated and deciphered to build theory.

\section{Discussion and conclusions}

Understanding the dynamics and factors underpinning the evolution of economic regions will allow light to be shed on one of the most critical issues confronting local economies, notably their capacity to be adaptive in order to constantly recreate their competitive advantage and survive over time. This matter has lately emerged as one of the most pressing issues for any local economy competing in today's volatile global economic scenario. Confronted by such challenging tasks, scholars, practitioners, and policymakers have the opportunity to tap into the growing and yet underdeveloped literature of entrepreneurial ecosystems to explore an alternative approach to gauge local competitiveness. In particular, we suggest that an explicit focus on the evolution of entrepreneurial ecosystems can offer an effective approach to assess the dynamics underpinning the transformation of local economies across space and over time. In this article, we traced a future research roadmap on the evolutionary processes of entrepreneurial ecosystems. Foremost, amongst these are the appropriate and evolving boundaries of the ecosystem, the internal and external sources of new knowledge and the actors blending them with the existing knowledge base, and whether the evolution is guided by the visible hand of Government or is it less visibly anchored by large corporations, often MNEs, or institutions such as local universities. Additionally, shedding light on the intersection between local and global knowledge circuits will be a fundamental element of a new effective research approach.

Tackling these research issues matters for several reasons. First, it will help to shed further light on a topic — the evolution of entrepreneurial ecosystems — that has received only limited attention to date, and that is still largely underdeveloped. Related to this reason is the need to draw the boundaries of an ecosystems and to track them as they evolve. This necessarily requires the study of both the geographical and technological dimensions of an ecosystem's boundaries, a condition that will allow a better definition of the nature and characteristics of any ecosystem. A second motivation to further develop the study of evolutionary entrepreneurial ecosystems relates to the growing intersection of local and global dynamics. As regional economies are increasingly partaking in global value chains, understanding how new knowledge flows into localized ecosystem and supports the establishment of new entrepreneurial activities in related and unrelated technological domains represents a necessary condition in the study of the competitiveness of regional economies.

The study of the evolution of entrepreneurial ecosystems through the analysis of the transformation of their boundaries and the intersection of local and global 
dynamics will not only open up new research opportunities, but should provide additional policy implications. Above all, we argue that our work offers three specific implications to local institutions and policymakers in general. First, we believe that the comprehension of the key dynamics underlying the evolution of entrepreneurial ecosystems will support policymakers' ability to make decisions in support of the competitiveness of their local economy. In a global context which has become particularly turbulent and volatile in recent times, assessing the mechanisms that drive change in the specialization and competitive advantage of places will be a sine qua non condition for the definition of any robust industrial policy agenda. A static approach, on the contrary, could dangerously lead policymakers to a condition of 'cognitive redundancy' (Uzzi, 1997) and 'cognitive myopia' (Maskell \& Malmberg, 2007). Second, tracking the evolution of entrepreneurial firms within an ecosystem will allow policymakers to assess the evolutionary trajectory of firms' specialization and sources of competitive advantage. This, in turn, will permit a finer analysis of the specific resources that are required by local firms and pave the way for the development of ad hoc industrial policies. Lastly, a clear understanding of the historical evolution of a local entrepreneurial ecosystem will equip policymakers with invaluable insights into the resources that a local system must attract from outside its boundaries to remain competitive over time. From foreign direct investments to the connection to global pipelines and global value chains, assessing the evolution of context-specific capabilities, resources, and constraints will represent the necessary starting point for any outward-looking strategic policy decisions.

Funding Open Access funding provided by the IReL Consortium.

Declarations We, the authors, declare that we have no competing interests in terms of employment, prior or current, nor any financial interests or proprietary interests. Neither was any funding received to assist with the preparation of this manuscript. No ethics approval was required in the preparation of our review document.

Open Access This article is licensed under a Creative Commons Attribution 4.0 International License, which permits use, sharing, adaptation, distribution and reproduction in any medium or format, as long as you give appropriate credit to the original author(s) and the source, provide a link to the Creative Commons licence, and indicate if changes were made. The images or other third party material in this article are included in the article's Creative
Commons licence, unless indicated otherwise in a credit line to the material. If material is not included in the article's Creative Commons licence and your intended use is not permitted by statutory regulation or exceeds the permitted use, you will need to obtain permission directly from the copyright holder. To view a copy of this licence, visit http://creativecommons. org/licenses/by/4.0/.

\section{References}

Acs, Z. J., Audretsch, D. B., \& Lehmann, E. E. (2013). The knowledge spillover theory of entrepreneurship. Small Business Economics, 41(4), 757-774. https://doi. org/10.1007/s11187-013-9505-9.

Acs, Z. J., Autio, E., \& Szerb, L. (2014). National Systems of Entrepreneurship: Measurement issues and policy implications. Research Policy, 43(3), 476-494. https://doi. org/10.1016/j.respol.2013.08.016.

Acs, Z. J., Stam, E., Audretsch, D. B., \& O’Connor, A. (2017). The lineages of the entrepreneurial ecosystem approach. Small Business Economics, 49(1), 1-10. https://doi. org/10.1007/s11187-017-9864-8.

Adams, S. B. (2020). From orchards to chips: Silicon Valley's evolving entrepreneurial ecosystem. Entrepreneurship \& Regional Development, 1-21. https://doi.org/10.1080 /08985626.2020.1734259.

Agrawal, A., \& Cockburn, I. (2003). The anchor tenant hypothesis: Exploring the role of large, local, R\&D-intensive firms in regional innovation systems. International Journal of Industrial Organization, 21(9), 1227-1253. https://doi. org/10.1016/S0167-7187(03)00081-X.

Alvedalen, J., \& Boschma, R. (2017). A critical review of entrepreneurial ecosystems research: Towards a future research agenda. European Planning Studies, 25(6), 887-903. https://doi.org/10.1080/09654313.2017.1299694.

Audretsch, D. B., \& Belitski, M. (2013). The missing pillar: The creativity theory of knowledge spillover entrepreneurship. Small Business Economics, 41(4), 819-836. https://doi. org/10.1007/s11187-013-9508-6.

Audretsch, D. B., \& Belitski, M. (2017). Entrepreneurial ecosystems in cities: Establishing the framework conditions. Journal of Technology Transfer, 42(5), 1030-1051. https://doi.org/10.1007/s10961-016-9473-8.

Audretsch, D. B., \& Keilbach, M. (2008). Resolving the knowledge paradox: Knowledge-spillover entrepreneurship and economic growth. Research Policy, 37(10), 1697-1705. https://doi.org/10.1016/j.respol.2008.08.008.

Auerswald, P. E. (2015). Enabling entrepreneurial ecosystems: Insights from ecology to inform effective entrepreneurship policy. SSRN Electronic Journal. https://doi.org/10.2139 /ssrn.2673843.

Auerswald, P. E., \& Dani, L. (2017). The adaptive life cycle of entrepreneurial ecosystems: The biotechnology cluster. Small Business Economics, 49(1), 97-117. https://doi.org/10.1007 /s11187-017-9869-3.

Autio, E., Kenney, M., Mustar, P., Siegel, D., \& Wright, M. (2014). Entrepreneurial innovation: The importance of 
context. Research Policy, 43(7), 1097-1108. https://doi. org/10.1016/j.respol.2014.01.015.

Autio, E., Nambisan, S., Thomas, L. D. W., \& Wright, M. (2018). Digital affordances, spatial affordances, and the genesis of entrepreneurial ecosystems. Strategic Entrepreneurship Journal, 12(1), 72-95. https://doi.org/10.1002/sej.1266.

Baron, T., \& Harima, A. (2019). The role of diaspora entrepreneurs in start-up ecosystem development - a Berlin case study. International Journal of Entrepreneurship and Small Business, 36(1/2), 74. https://doi.org/10.1504/IJESB.2019.096968.

Berrill, J., O'Hagan-Luff, M., \& van Stel, A. (2020). The moderating role of education in the relationship between FDI and entrepreneurial activity. Small Business Economics, 54(4), 1041-1059. https://doi.org/10.1007/s11187-018-0121-6.

Bhawe, N., \& Zahra, S. A. (2019). Inducing heterogeneity in local entrepreneurial ecosystems: The role of MNEs. Small Business Economics, 52(2), 437-454. https://doi. org/10.1007/s11187-017-9954-7.

Bhawe, N., Zahra, S. A., Chao, C., \& Bruton, G. D. (2019). Protectionist policies and diversity of entrepreneurial types. Small Business Economics, 1-19. https://doi.org/10.1007 /s11187-019-00269-z.

Boschma, R. (2015). Towards an evolutionary perspective on regional resilience. Regional Studies, 49(5), 733-751. https://doi.org/10.1080/00343404.2014.959481.

Boschma, R., \& Frenken, K. (2011). The emerging empirics of evolutionary economic geography. Journal of economic geography, 11(2), 295-307. https://doi.org/10.1093 /jeg/lbq053.

Bosma, N., Content, J., Sanders, M., \& Stam, E. (2018). Institutions, entrepreneurship, and economic growth in Europe. Small Business Economics, 51(2), 483-499. https://doi.org/10.1007/s11187-018-0012-x.

Braun, V., \& Clarke, V. (2006). Using thematic analysis in psychology. Qualitative research in psychology, 3(2), 77-101. https://doi.org/10.1191/1478088706qp063oa.

Breschi, S., \& Lissoni, F. (2003). Mobility and social networks: Localised knowledge spillovers revisited. Università commerciale Luigi Bocconi.

Breznitz, S. M., \& Zhang, Q. (2019). Fostering the growth of student start-ups from university accelerators: An entrepreneurial ecosystem perspective. Industrial and Corporate Change, 28(4), 855-873. https://doi.org/10.1093/icc/dtz033.

Brown, R., \& Mason, C. (2017). Looking inside the spiky bits: A critical review and conceptualisation of entrepreneurial ecosystems. Small Business Economics, 49(1), 11-30. https://doi.org/10.1007/s11187-017-9865-7.

Buciuni, G., \& Pisano, G. (2018). Knowledge integrators and the survival of manufacturing clusters. Journal of Economic Geography, 18(5), 1069-1089. https://doi.org/10.1093 /jeg/lby035.

Buciuni, G., \& Pisano, G. (2021). Variety of innovation in global value chains. Journal of World Business, 56(2), 101167. https://doi.org/10.1016/j.jwb.2020.101167.

Buenstorf, G., \& Klepper, S. (2009). Heritage and agglomeration: The Akron tyre cluster revisited. The Economic Journal, 119(537), 705-733. https://doi.org/10.1111/j.14680297.2009.02216.x.

Cantner, U., Cunningham, J. A., Lehmann, E. E., \& Menter, M. (2020). Entrepreneurial ecosystems: A dynamic lifecycle model. Small Business Economics. https://doi.org/10.1007 /s11187-020-00316-0.

Cao, Z., \& Shi, X. (2020). A systematic literature review of entrepreneurial ecosystems in advanced and emerging economies. Small Business Economics. https://doi.org/10.1007 /s11187-020-00326-y.

Cavallo, A., Ghezzi, A., \& Balocco, R. (2019). Entrepreneurial ecosystem research: Present debates and future directions. International Entrepreneurship and Management Journal, 15(4), 1291-1321. https://doi.org/10.1007/s11365-0180526-3.

Clarysse, B., Wright, M., Bruneel, J., \& Mahajan, A. (2014). Creating value in ecosystems: Crossing the chasm between knowledge and business ecosystems. Research Policy, 43(7), 1164-1176. https://doi.org/10.1016/j.respol.2014.04.014.

Cohen, B. (2006). Sustainable valley entrepreneurial ecosystems. Journal Business Strategy the Environment, 15(1), 1-14. https://doi.org/10.1002/bse.428.

Colombelli, A., Paolucci, E., \& Ughetto, E. (2019). Hierarchical and relational governance and the life cycle of entrepreneurial ecosystems. Small Business Economics, 52(2), 505-521. https://doi.org/10.1007/s11187-017-9957-4.

Colombo, M. G., Dagnino, G. B., Lehmann, E. E., \& Salmador, M. P. (2019). The governance of entrepreneurial ecosystems. Small Business Economics, 52(2), 419-428. https://doi. org/10.1007/s11187-017-9952-9.

Cukier, D., Kon, F., \& Krueger, N. (2015). Towards a software startup ecosystems maturity model. Department of Computer Science-University of São Paulo Technical Report RT-MAC.

Cumming, D., Werth, J. C., \& Zhang, Y. (2019). Governance in entrepreneurial ecosystems: Venture capitalists vs. technology parks. Small Business Economics, 52(2), 455-484. https://doi.org/10.1007/s11187-017-9955-6.

Cunningham, J. A., Menter, M., \& Wirsching, K. (2019). Entrepreneurial ecosystem governance: A principal investigator-centered governance framework. Small Business Economics, 52(2), 545-562. https://doi. org/10.1007/s11187-017-9959-2.

Dabić, M., Maley, J., Dana, L. P., Novak, I., Pellegrini, M. M., \& Caputo, A. (2019). Pathways of SME internationalization: A bibliometric and systematic review. Small Business Economics, 1-21. https://doi.org/10.1007/s11187-01900181-6.

De Backer, K., \& Sleuwaegen, L. (2003). Does foreign direct investment crowd out domestic entrepreneurship? Review of industrial organization, 22(1), 67-84. https://doi. org/10.1023/A:1022180317898.

Donegan, M., Forbes, A., Clayton, P., Polly, A., Feldman, M., \& Lowe, N. (2019). The tortoise, the hare, and the hybrid: Effects of prior employment on the development of an entrepreneurial ecosystem. Industrial and Corporate Change, 28(4), 899-920. https://doi.org/10.1093/icc/dtz037.

Feld, B. (2012). Startup Communities: Building an entrepreneurial ecosystem in your city. John Wiley \& Sons, Inc. John Wiley \& Sons. https://doi.org/10.1016/j.ijhydene.2011.08.022

Feldman, M. (2003). The locational dynamics of the U.S. biotech industry: Knowledge externalities and the anchor hypothesis. In Research and Technological Innovation (Vol. 10, pp. 201-224). Physica-Verlag. https://doi.org/10.1007/3-79081658-2 9 . 
Feldman, M. P., \& Kogler, D. F. (2010). Stylized facts in the geography of innovation. In Handbook of the economics of innovation (Vol. 1, pp. 381-410). Elsevier. https://doi. org/10.1016/S0169-7218(10)01008-7.

Fuerlinger, G., Fandl, U., \& Funke, T. (2015). The role of the state in the entrepreneurship ecosystem: Insights from Germany. Triple Helix, 2(1), 3. https://doi.org/10.1186/s40604-0140015-9.

Gauthier, J. F., Penzel, M., \& Marmer, M. (2017). Global startup ecosystem report 2017. San Francisco: Startupgenome. https://doi.org/10.1096/fj.00.

Ghio, N., Guerini, M., \& Rossi-Lamastra, C. (2019). The creation of high-tech ventures in entrepreneurial ecosystems: Exploring the interactions among university knowledge, cooperative banks, and individual attitudes. Small Business Economics, 52(2), 523-543. https://doi.org/10.1007 /s11187-017-9958-3.

Giblin, M., \& Ryan, P. (2012). Tight clusters or loose networks? The critical role of inward foreign direct investment in cluster creation. Regional Studies, 46(2), 245-258. https://doi. org/10.1080/00343404.2010.497137.

Grégoire, D. A., \& Cherchem, N. (2020). A structured literature review and suggestions for future effectuation research. Small Business Economics, 54(3), 621-639. https://doi. org/10.1007/s11187-019-00158-5.

Haarhaus, T., Strunk, G., \& Liening, A. (2020). Assessing the complex dynamics of entrepreneurial ecosystems: A nonstationary approach. Journal of Business Venturing Insights, 14, e00194. https://doi.org/10.1016/j.jbvi.2020.e00194.

Hakala, H., O'Shea, G., Farny, S., \& Luoto, S. (2020). Re-storying the business, innovation and entrepreneurial ecosystem concepts: The model-narrative review method. International Journal of Management Reviews, 22(1), 10-32. https://doi. org/10.1111/ijmr.12212.

Han, J., Ruan, Y., Wang, Y., \& Zhou, H. (2019). Toward a complex adaptive system: The case of the Zhongguancun entrepreneurship ecosystem. Journal of Business Research. https://doi.org/10.1016/j.jbusres.2019.11.077.

Hannan, M., \& Freeman, J. (1989). Organizational Ecology. Cambridge, Massachusetts; London, England: Harvard University Press. https://doi.org/10.2307/j.ctvjz813k

Harima, A., Harima, J., \& Freiling, J. (2020). The injection of resources by transnational entrepreneurs: Towards a model of the early evolution of an entrepreneurial ecosystem. Entrepreneurship \& Regional Development, 1-28. https://doi.org/10.1080/08985626.2020.1734265.

Hassink, R., \& Shin, D. (2005). South Korea's shipbuilding industry: From a couple of Cathedrals in the desert to an innovative cluster. Asian Journal of Technology Innovation, 13(2), 133155. https://doi.org/10.1080/19761597.2005.9668611.

Hayter, C. S. (2016). A trajectory of early-stage spinoff success: The role of knowledge intermediaries within an entrepreneurial university ecosystem. Small Business Economics, 47(3), 633-656. https://doi.org/10.1007/s11187-016-9756-3.

Hayter, C. S., Nelson, A. J., Zayed, S., \& O’Connor, A. C. (2018). Conceptualizing academic entrepreneurship ecosystems: A review, analysis and extension of the literature. The Journal of Technology Transfer, 43(4), 1039-1082. https://doi. org/10.1007/s10961-018-9657-5.

Hechavarría, D. M., \& Ingram, A. E. (2019). Entrepreneurial ecosystem conditions and gendered national-level entrepreneurial activity: A 14-year panel study of GEM. Small Business Economics, 53(2), 431-458. https://doi. org/10.1007/s11187-018-9994-7.

Hidalgo, C. A., \& Hausmann, R. (2009). The building blocks of economic complexity. Proceedings of the National Academy of Sciences, 106(26), 10570-10575. https://doi.org/10.1073 /pnas.0900943106.

Hochberg, Y. V. (2016). Accelerating entrepreneurs and ecosystems: The seed accelerator model. Innovation Policy and the Economy, 16, 25-51. https://doi.org/10.1086/684985.

Holling, C. S., \& Gunderson, L. H. (2002). Resilience and adaptive cycles. In: Panarchy: Understanding transformations in human and natural systems, 25-62. http://hdl.handle. net/10919/67621

Isenberg, D. (2010). How to start an entrepreneurial revolution. Harvard business review, 88(6), 40-50 http://elib.tcd. ie/login?url=https://search.proquest.com/docview/366285339 ?accountid=14404.

Isenberg, D.. (2011). The entrepreneurship ecosystem strategy as a new paradigm for economy policy: Principles for cultivating entrepreneurship. Babson entrepreneurship ecosystem project, Babson college, Babson Park: MA.

Johnson, D., Bock, A. J., \& George, G. (2019). Entrepreneurial dynamism and the built environment in the evolution of university entrepreneurial ecosystems. Industrial and Corporate Change, 28(4), 941-959. https://doi.org/10.1093 /icc/dtz034.

Karami, M., Wooliscroft, B., \& McNeill, L. (2019). Effectuation and internationalisation: A review and agenda for future research. Small Business Economics. https://doi.org/10.1007 /s11187-019-00183-4.

Kedron, P., Kogler, D., \& Rocchetta, S. (2019). Mind the gap: Advancing evolutionary approaches to regional development with progressive empirical strategies. Geography Compass, e12501. https://doi.org/10.1111/gec3.12501.

Klepper, S. (1996). Entry, exit, growth, and innovation over the product life cycle. American Economic Review, 86(3), 562583. https://doi.org/10.2307/2118212.

Klepper, S. (2002). The capabilities of new firms and the evolution of the US automobile industry. Industrial and Corporate Change, 11(4), 645-666. https://doi.org/10.1093 /icc/11.4.645.

Klepper, S. (2007). Disagreements, spinoffs, and the evolution of detroit as the capital of the U.S. automobile industry. Management Science, 53(4), 616-631. https://doi. org/10.1287/mnsc.1060.0683.

Kogler, D. F. (2015). Editorial: Evolutionary economic geography Theoretical and empirical progress. Regional Studies, 49(5), 705-711. https://doi.org/10.1080/00343404.2015.1033178.

Kuckertz, A. (2019). Let's take the entrepreneurial ecosystem metaphor seriously! Journal of Business Venturing Insights, 11, e00124. https://doi.org/10.1016/j.jbvi.2019.e00124.

Kuratko, D. F., Morris, M. H., \& Schindehutte, M. (2015). Understanding the dynamics of entrepreneurship through framework approaches. Small Business Economics, 45(1), 1-13. https://doi.org/10.1007/s11187-015-9627-3.

Lai, Y., \& Vonortas, N. S. (2019). Regional entrepreneurial ecosystems in China. Industrial and Corporate Change, 28(4), 875-897. https://doi.org/10.1093/icc/dtz035. 
Langley, A. (2007). Process thinking in strategic organization. Strategic Organization, 5(3), 271-282. https://doi. org/10.1177/1476127007079965.

Liñán, F., \& Fayolle, A. (2015). A systematic literature review on entrepreneurial intentions: Citation, thematic analyses, and research agenda. International Entrepreneurship and Management Journal, 11(4), 907-933. https://doi. org/10.1007/s11365-015-0356-5.

Mack, E., \& Mayer, H. (2016). The evolutionary dynamics of entrepreneurial ecosystems. Urban Studies, 53(10), 21182133. https://doi.org/10.1177/0042098015586547.

Malecki, E. J. (2018). Entrepreneurship and entrepreneurial ecosystems. Geography Compass, 12(3), e12359. https://doi. org $/ 10.1111 /$ gec 3.12359 .

Markusen, A. (1996). Sticky places in slippery space: A typology of industrial districts. Economic Geography, 72(3), 293-313. https://doi.org/10.2307/144402.

Martin, R., \& Sunley, P. (2011). Conceptualizing cluster evolution: Beyond the life cycle model? Regional Studies, 45(10), 1299-1318. https://doi.org/10.1080/00343404.2011.622263.

Martin, R., \& Sunley, P. (2015). Towards a developmental turn in evolutionary economic geography? Regional Studies, 49(5), 712-732. https://doi.org/10.1080/00343404.2014.899431.

Maskell, P., \& Malmberg, A. (2007). Myopia, knowledge development and cluster evolution. Journal of Economic Geography, 7(5), 603-618. https://doi.org/10.1093 /jeg/lbm020.

Mason, C., \& Brown, R. (2013). Creating good public policy to support high-growth firms. Small Business Economics, 40(2), 211-225. https://doi.org/10.1007/s11187-011-9369-9.

Mason, C., \& Brown, R. (2014). Entrepreneurial ecosystems and growth oriented entrepreneurship. Oecd, 30(1), 1-38. https://doi.org/10.1007/s13398-014-0173-7.2.

Mason, C. M., \& Harrison, R. T. (2006). After the exit: Acquisitions, entrepreneurial recycling and regional economic development. Regional Studies, 40(1), 55-73. https://doi. org/10.1080/00343400500450059.

Meoli, M., \& Vismara, S. (2016). University support and the creation of technology and non-technology academic spinoffs. Small Business Economics, 47(2), 345-362. https://doi. org/10.1007/s11187-016-9721-1.

Meoli, M., Paleari, S., \& Vismara, S. (2019). The governance of universities and the establishment of academic spin-offs. Small Business Economics, 52(2), 485-504. https://doi. org/10.1007/s11187-017-9956-5.

Miller, D. J., \& Acs, Z. J. (2017). The campus as entrepreneurial ecosystem: The University of Chicago. Small Business Economics, 49(1), 75-95. https://doi.org/10.1007/s11187017-9868-4.

Mochkabadi, K., \& Volkmann, C. K. (2020). Equity crowdfunding: A systematic review of the literature. Small Business Economics, 54(1), 75-118. https://doi.org/10.1007 /s11187-018-0081-x.

Moore, J. F. (1993). Predators and prey: A new ecology of competition. Harvard Business Review, 71(3), 75-86.

Motoyama, Y., \& Knowlton, K. (2017). Examining the connections within the startup ecosystem: A case study of St. Louis. Entrepreneurship Research Journal, 7(1). https://doi. org/10.1515/erj-2016-0011.

Mudambi, R., Mudambi, S. M., Mukherjee, D., \& Scalera, V. G. (2017). Global connectivity and the evolution of industrial clusters: From tires to polymers in Northeast Ohio. Industrial Marketing Management, 61, 20-29. https://doi.org/10.1016 j.indmarman.2016.07.007.

Mulas, V., Minges, M., \& Applebaum, H. (2016). Boosting tech innovation: Ecosystems in cities: A framework for growth and sustainability of urban tech innovation ecosystems. Innovations: Technology, Governance, Globalization, 11(1-2), 98-125. https://doi.org/10.1162/inov_a_00251.

Murmann, J. P., \& Frenken, K. (2006). Toward a systematic framework for research on dominant designs, technological innovations, and industrial change. Research Policy, 35(7), 925-952. https://doi.org/10.1016/j.respol.2006.04.011.

Napier, G., \& Hansen, C. (2011). Ecosystems for young highgrowth firms. J FORA Group, (February), 1-24.

Narula, R. (2002). Innovation systems and 'inertia' in R\&D location: Norwegian firms and the role of systemic lock-in. Research Policy, 31(5), 795-816. https://doi.org/10.1016 /S0048-7333(01)00148-2.

Nicholls-Nixon, C. L., Valliere, D., Gedeon, S. A., \& Wise, S. (2020). Entrepreneurial ecosystems and the lifecycle of university business incubators: An integrative case study. International Entrepreneurship and Management Journal. https://doi.org/10.1007/s11365-019-00622-4.

O'Connor, A., Stam, E., Sussan, F., \& Audretsch, D. B. (2018). Entrepreneurial ecosystems: The foundations of place-based renewal. In Entrepreneurial ecosystems (pp. 1-21). Springer. https://doi.org/10.1007/978-3-319-63531-6_1.

O'Shea, G., Farny, S., \& Hakala, H. (2019). The buzz before business: A design science study of a sustainable entrepreneurial ecosystem. Small Business Economics. https://doi. org/10.1007/s11187-019-00256-4

Perri, A., Scalera, V. G., \& Mudambi, R. (2017). What are the most promising conduits for foreign knowledge inflows? Innovation networks in the Chinese pharmaceutical industry. Industrial and Corporate Change, 26(2), 333-355. https://doi.org/10.1093/icc/dtx004.

Pettigrew, A. M. (1990). Longitudinal field research on change: Theory and practice. Organization Science, 1(3), 267-292. https://doi.org/10.1287/orsc.1.3.267.

Pitelis, C. (2012). Clusters, entrepreneurial ecosystem co-creation, and appropriability: A conceptual framework. Industrial and Corporate Change, 21(6), 1359-1388. https://doi. org/10.1093/icc/dts008.

Pittaway, L., \& Cope, J. (2007). Entrepreneurship education: A systematic review of the evidence. International Small Business Journal. https://doi.org/10.1177/0266242607080656.

Qin, F., Wright, M., \& Gao, J. (2019). Accelerators and intraecosystem variety: How entrepreneurial agency influences venture development in a time-compressed support program. Industrial and Corporate Change, 28(4), 961-975. https://doi.org/10.1093/icc/dtz036.

Roundy, P. T. (2017). Hybrid organizations and the logics of entrepreneurial ecosystems. International Entrepreneurship and Management Journal, 13(4), 1221-1237. https://doi. org/10.1007/s11365-017-0452-9.

Roundy, P. T., Bradshaw, M., \& Brockman, B. K. (2018). The emergence of entrepreneurial ecosystems: A complex adaptive systems approach. Journal of Business Research, 86, 110. https://doi.org/10.1016/j.jbusres.2018.01.032.

Ryan, P., Giblin, M., Andersson, U., \& Clancy, J. (2018). Subsidiary knowledge creation in co-evolving contexts. 
International Business Review, 27(5), 915-932. https://doi. org/10.1016/j.ibusrev.2018.02.003.

Ryan, P., Giblin, M., Buciuni, G., \& Kogler, D. F. (2020). The role of MNEs in the genesis and growth of a resilient entrepreneurial ecosystem. Entrepreneurship \& Regional Development, 118. https://doi.org/10.1080/08985626.2020.1734260.

Schäfer, S., \& Henn, S. (2018). The evolution of entrepreneurial ecosystems and the critical role of migrants. A phase-model based on a study of IT startups in the Greater Tel Aviv Area. Cambridge Journal of Regions, Economy and Society, 11(2), 317-333.

Schumpeter, J. (1911). The theory of economic development. Harvard Economic Studies. Vol. XLVI. Cambridge, MA: Harvard University Press.

Shane, S., \& Venkataraman, S. (2000). The promise of entrepreneurship as a field of research. Academy of Management Review, 25(1), 217-226. https://doi.org/10.5465 /AMR.2000.2791611.

Song, A. K. (2019). The Digital Entrepreneurial Ecosystem-a critique and reconfiguration. Small Business Economics, 53(3), 569-590. https://doi.org/10.1007/s11187-019-00232$\mathrm{y}$.

Spigel, B. (2017). The relational organization of entrepreneurial ecosystems. Entrepreneurship: Theory and Practice, 41(1), 49-72. https://doi.org/10.1111/etap.12167.

Spigel, B., \& Harrison, R. (2018). Toward a process theory of entrepreneurial ecosystems. Strategic Entrepreneurship Journal, 12(1), 151-168. https://doi.org/10.1002/sej.1268.

Spigel, B., \& Vinodrai, T. (2020). Meeting its Waterloo? Recycling in entrepreneurial ecosystems after anchor firm collapse. Entrepreneurship \& Regional Development, 1-22. https://doi.org/10.1080/08985626.2020.1734262.

Stam, E. (2015). Entrepreneurial ecosystems and regional policy: A sympathetic critique. European Planning Studies, 23(9), 1759-1769. https://doi.org/10.1080/09654313.2015.1061484.

Stam, F. C., \& Spigel, B. (2016). Entrepreneurial ecosystems. USE Discussion paper series, 16(13).

Stam, E., \& van de Ven, A. (2019). Entrepreneurial ecosystem elements. Small Business Economics, 1-24. https://doi. org/10.1007/s11187-019-00270-6.
Sussan, F., \& Acs, Z. J. (2017). The digital entrepreneurial ecosystem. Small Business Economics, 49(1), 55-73. https://doi. org/10.1007/s11187-017-9867-5.

Theodoraki, C., Messeghem, K., \& Rice, M. P. (2018). A social capital approach to the development of sustainable entrepreneurial ecosystems: An explorative study. Small Business Economics, 51(1), 153-170 https://doi.org/10.1007/s11187017-9924-0.

Thompson, T. A., Purdy, J. M., \& Ventresca, M. J. (2018). How entrepreneurial ecosystems take form: Evidence from social impact initiatives in Seattle. Strategic Entrepreneurship Journal, 12(1), 96-116. https://doi.org/10.1002/sej.1285.

Tranfield, D., Denyer, D., \& Smart, P. (2003). Towards a methodology for developing evidence-informed management knowledge by means of systematic review. British Journal of Management. https://doi.org/10.1111/1467-8551.00375.

Uzzi, B. (1997). Social structure and competition in interfirm networks: The paradox of embeddedness. Administrative Science Quarterly, 42(1), 35-67. https://doi.org/10.2307 12393808 .

Van De Ven, H. (1993). The development of an infrastructure for entrepreneurship. Journal of Business Venturing, 8(3), 211230. https://doi.org/10.1016/0883-9026(93)90028-4.

Vedula, S., \& Kim, P. H. (2019). Gimme shelter or fade away: The impact of regional entrepreneurial ecosystem quality on venture survival. Industrial and Corporate Change, 28(4), 827854. https://doi.org/10.1093/icc/dtz032.

Welch, C., \& Paavilainen-Mäntymäki, E. (2014). Putting Process (Back) In: Research on the internationalization process of the firm. International Journal of Management Reviews, 16(1), 2-23. https://doi.org/10.1111/ijmr.12006.

Williams, N., \& Vorley, T. (2014). Economic resilience and entrepreneurship: Lessons from the Sheffield City Region. Entrepreneurship \& Regional Development, 26(3-4), 257281. https://doi.org/10.1080/08985626.2014.894129.

Publisher's note Springer Nature remains neutral with regard to jurisdictional claims in published maps and institutional affiliations. 